\title{
PERSEPSI MAHASISWA TERHADAP PEMBELAJARAN DARING PERSPEKTIF NEUROSAINS PENDIDIKAN ISLAM
}

\author{
Muhammad Miftakhurrohman', ${ }^{1}$ Suyadi $^{2}$ \\ ${ }^{1,2}$ Fakultas Agama Islam, Universitas Ahmad Dahlan \\ Email: 11M1900031153@webmail.uad.ac.id; ${ }^{2}$ suyadi@fai.uad.ac.id
}

\begin{abstract}
Abstrak
Pembelajaran daring adalah sebuah upaya dalam lembaga pendidikan untuk mengadakan belajar mengajar berbasis online dengan maksud agar pembelajaran tetap berjalan sesuai sistem yang ditentukan sebelumnya. Kebijakan ini disebabkan oleh adanya pandemi virus corona (COVID-19) yang terus menyebar dan memakan korban. Penelitian ini bertujuan untuk menjelaskan dampak dari perkuliahan daring dalam perspektif neurosains pendidikan Islam. Penelitian ini menggunakan metode kualitatif, dengan teknik mengmpulkan data yang bersumber dari buku, dan jurnal-jurnal penelitian yang difokuskan pada topik penelitian. Hasil penelitian menunjukkan bahwa dampak pembelajaran daring membuat para mahasiswa mengalami keresahan mulai dari tidak paham pengaplikasian dan sistem yang diterapkan, adapun pengaruh tekanan batin dari virus corona, yang tentunya membuat tidak sedikit mahasiswa merasa stres. Karena secara neurosains otak memiliki hormon bahagia yaitu hormon dopamin yang merespon segala keadaan yang diterima otak. Begitu pula pandangan pendidikan Islam dalam menafikan ini adalah suatu hal yang tidak sewajarnya terjadi, karena secara tidak langsung merugikan di satu pihak yaitu mahasiswa.
\end{abstract}

Kata kunci: Daring, Mahasiswa, Pendidikan Islam, Neurosains, Covid-19.

\begin{abstract}
Online learning is an effort in educational institutions to hold online-based teaching and learning with the intention that the learning process continues according to a predetermined system. This policy is caused by the corona virus pandemic (COVID-19) which continues to spread and take its toll. This study aims to explain the impact of online lectures in the neuroscience perspective of Islamic education.This study uses qualitative methods, with techniques for collecting data sourced from books, and research journals that are focused on the topic of research.. The results showed that the impact of online learning caused students to experience anxiety ranging from not understanding the application and the applied system, as for the influence of inner pressure from the coronavirus, which certainly made many students feel stressed. Because neuroscience the brain has a happy hormone that is the hormone dopamine which responds to all conditions that the brain receives. Likewise, the view of Islamic education in denying this is something that is not natural to happen, because it is indirectly detrimental to one party, namely students.
\end{abstract}

Keywords: Online, Students, Islamic Education, Neuroscience, Covid-19. 


\section{A. PENDAHULUAN}

Pembelajaran daring adalah suatu proses pembelajaran yang memanfaatkan teknologi keajuan jaman yang dapat dijangkau dari berbagai (Mustofa et al., 2019). Di bangku perkuliahan sistem pembelajaran daring dikenal dengan perkuliahan daring. Sistem perkuliahan daring sudah sangat dikenal oleh kalangan mahasiswa dalam perkuliahannya. Namun kala itu tidak semua mata kuliah menerapkan perkuliahan daring, melainkan hanya beberapa. Pada akhirnya saat ini perkuliahan daring benar-benar diterapkan untuk semua mata kuliah, bahkan semua perguruan tinggi yang ada di Indonesia.

Salah satu sebab terjadinya penerapan perkuliahan daring secara masal ini adalah akibat semakin merebaknya virus corona (COVID-19). Coronavirus Disease 2019 atau COVID-19 adalah sebuah penyakit yang terbaru yang berimbas pada gangguan pernapasan dan radang paru. Penyebab dari penyakit ini akibat infeksi Severe Acute Respiratory Syndrome Coronavirus 2 (SARS-CoV-2). Gejala awal yang terlihat sebab virus corona bermacam, seperti gejala flu biasa (demam, batuk, pilek, nyeri tenggorokan, nyeri otot, nyeri kepala) sampai yang komplikasi berat (pneumonia atau sepsis) (Fauzia, 2020). Hal ini selain menyebabkan terganggunya sistem belajar mengajar dan juga mengancam perekonomian negara. Karena adanya virus corona ini seluruh rakyat Indonesia dihimbau untuk melakukan seluruh aktifitas di dalam rumah (social distance) ataupun karantina mandiri agar tidak tertular dan ketika telah terpapar tidak menularkan. Karantina adalah sebuah cara yang turun-temurun dianggap paling efektif mengatasi persebaran penyakit menular. Cara seperti ini digunakan secara meluas oleh bangsa Italia pada abad ke-14. (Wilder-Smith \& Freedman, 2020). Dan ketika melakukan aktifitas di luar rumah ditekankan menggunakan masker serta menggunakan hand sanitizer, karena dengan upaya ini setidaknya mampu membuat steril permukaan tubuh yang telah terkena biocidal. Penggunaan biocidal sangatlah berguna seperti hidrogen peroksida, alkohol, natrium hipoklorit atau benzalkonium klorida digunakan di seluruh dunia untuk desinfeksi, pastinya yang utama untuk bidang kesehatan (Kampf et al., 2020). Karena biocidal ini sangat berguna untuk mematikan bakteri yang ada di permukaan kulit manusia hanya dalam hitungan detik.

Berjalan seiring waktu banyak terdapat keluhan mahasiswa mengenai perkuliahan daring. Sebab setiap mata kuliah tidak menggunakan sistem pendukung yang sama, seperti edmodo, google classroom, zoom, hangouts, whatsapp, instagram, dan lainnya. Hal ini menyebabkan tidak sedikit mahasiswa merasa kesulitan dalam pengaplikasian aplikasi tersebut. Ditambah lagi melalui perkuliahan daring tugas semakin banyak dan sulit untuk berkontribusi langsung dengan dosen pengampu. Dan menimbulkan produksi hormon dopamin tidak optimal, sehingga mahasiswa merasa stres dan merasakan tekanan batin. Pokok permasalahan inilah yang akan dibahas dalam penelitian ini.

Dalam neurosains dopamin atau dengan nama IUPAC 4-(2-aminoethyl)benzene-1,2-diol (DA) adalah suatu bentuk katekolamin alami yang perannya sangat dibutuhkan sebagai neurotransmitter tentunya di sistem kehormonan, sistem saraf kardiovaskuler dan saraf inti/pusat (Irdhawati et al., 2015). Hormon dopamin juga disebut sebagai hormon pengendali emosi. Saat dilepaskan dalam jumlah yang tepat, hormon ini akan meningkatkan suasana hati, sehingga orang akan merasa lebih senang dan bahagia. Sebaliknya, kekurangan hormon dopamin akan membuat suasana hati menjadi buruk, bahkan dapat meningkatkan risiko terjadinya depresi. 
Problem tugas yang semakin banyak, hal ini secara tidak langsung memanipulasi pemikiran mahasiswa bahwasanya problem ini tergolong ke sesuatu yang berlebihan dalam Islam. Ditambah lagi adanya unsur dorongan dari luar yaitu lembaga pendidikan memberikan peringatan untuk SDM pengajarnya dihimbau mengurangi beberapa program tugasnya disebabkan banyak menerima keluhan dari para mahasiswa. Pada akhirnya Sekolah atau lembaga pendidikan menjadi tidak sejalan dengan pemikiran peserta didik/mahasiswa. Sementara bentuk pendidikan pada umumnya adalah yang didominasi dengan pemikiran yang menggunakan otak kiri. Yang mempunyai kelemahan sulit dalam memahami bagaimana orang lain memiliki sudut pandang yang berbeda dalam mencerna keadaan sekitar (Saifurrahman; Suyadi, 2019) .

Penelitian Eko Kuntarto tentang keefektifan model pembelajaran daring dalam perkuliahan bahasa indonesia di perguruan tinggi perlu mendapatkan perhatian khusus mengingat perspektif yang ditekankan adalah keunggulan dari teknologi berbasis komputer. Penelitian Eko Kuntarto menunjukkan bahwa pembelajaran akan lebih asik atau menyenangan jika di imbangi dengan sistem berbasis online (daring) (Kuntarto, 2017).

Penelitian Mokhamad Iklil Mustofa, Muhammad Chodzirin, Lina Sayekti tentang upaya pembelajaran daring yang dipercaya digunakan untuk meningkatkan kualitas dan kuantitas suatu instansi/perguruan tinggi. Penelitian ini membahas keunggulan dan kreativitas dalam pemanfaatan kuliah daring sangatlah diperlukan di era 4.0 ini karena setiap hal yang baru dapat berdampak positif dan berfungsi memajukan instansi yang dimilikinya, sehingga dapat bersaing dengan instansi terkemuka atau yang sudah tidak diragukan lagi keberadaanya (Mustofa et al., 2019).

Penelitian pada artikel ini sangat berbeda dengan penelitian diatas mengingat penelitian diatas hanya memperdalam dan menjelaskan dampak positif atau keunggulan dari perkuliahan daring. Persoalan yang hendak dijawab dalam penelitian ini adalah dampak negatif dari penggunaan perkuliahan daring dalam pandangan mahasiswa. Mengapa mahasiswa ? sebab mahasiswa adalah salah satu pihak komunikan dalam penyampaian komunikasi pendidikan dalam proses belajar mengajar. Jadi ide pembuatan penelitian ini tergagas dari suara mahasiswa yang mengeluh, serta penjajakan terhadap perkuliahan daring sendiri yang diterapkan secara masal saat ini dan belum diketahui sampai kapan akan berakhir, karena terikat dengan adanya virus corona (COVID-19) yang tidak kunjung dapat ditemukan vaksin penawarnya oleh lembaga kesehatan dunia.

\section{B. METODE PENELITIAN}

Metode penelitian menggunakan metode kepustakaan dengan menggunakan pendekatan kualitatif. Penelitian kualitatif ini mengutamakan sarana yang dimiliki oleh peneliti. Lincoln dan Guba mengemukakan bahwa dalam pendekatan kualitatif instrumen peneliti sangatlah dibutuhkan, sebab instrumen yang berasal dari luar manusia akan sulit dalam menerima realitas yang ada dan bentuk interaksi yang terjadi. Gejala yang ada di lapangan harus mampu dikemukakan oleh peneliti menggunakan pencernaan secara indrawi (Mulyadi, 2011). Mengingat metode kualitatif, sehingga teknik pengumpulan data bersumber dari buku-buku dan jurnaljurnal yang difokuskan pada tema penelitian. Dan teknik analisis yang digunakan adalah interpretatif dan wawancara komunikasi personal pada narasumber dalam problem terkait. Pendekatan ini berangkat dari upaya untuk mencari penjelasan tentang peristiwa sosial atau 
budaya yang didasarkan pada perspektif dan pengalaman orang atau organisasi yang diteliti. Penelitian ini dikategorikan ke dalam proses literasi neurosains dan pendidikan Islam.

\section{HASIL DAN PEMBAHASAN}

\section{Permasalahan Pembelajaran Daring}

Sajian dalam hasil dan pembahasan ditulis secara bersistem, hanya hasil data/informasi yang terkait dengan tujuan penelitian; sederhanakan tabel dan menggunakan tabel terbuka, dan gambar peta lebih difokuskan pada objek yang diteliti serta jangan terlalu besar ukuran filenya serta rumit (diupayakan dalam format JPG); tabel dan gambar diberi nomor urut. Contoh penulisan tabel: Tabel 3.

Pada saat ini alat teknologi, informasi, dan komunikasi sangat lah universal dalam proses peningkatan interaksi sosial, mengingat terjadinya kolaborasi dan komunikasi yang kompak pada kerja siswa online. Adanya pendidikan secara online mampu membantu pelajar sebagai ajang berdiskusi. Beberapa sarana dalam teknologi baik untuk mengembangkan pelajar dalam dunia internet ini sangat mudah di akses baik sistem web atau aplikasi khusus (Awada, 2016). Berdasarkan analisis pembelajaran daring yang diterapkan saat ini, pembelajaran daring sudah di masalkan karena turut membantu proses belajar mengajar yang terhalang adanya virus corona (COVID-19). Sebagian besar universitas di Indonesia telah menerapkan kelas jarak jauh atau kelas online, sebagai tindakan atas penyebaran virus Corona COVID-19. Selain belajar dan mengajar, sejumlah kampus di tanah air sudah mengambil kebijakan hingga akhir semester genap ini agar semua kegiatan perkuliahan dilakukan secara daring, termasuk ujian tengah semester, ujian akhir semester, praktikum, dan bimbingan tugas akhir, tesis, serta disertasi.

Sehingga dengan adanya pandemi ini pemerintah melakukan pembatasan dalam aktifitas diluar rumah termasuknya belajar mengajar atau disebut dengan karantina. Sebab itulah proses belajar mengajar dialihkan ke pembelajaran berbasis online. Penerapan pembelajaran daring ini tidak hanya diterapkan dibangku perkuliahan saja tetapi juga di bangku sekolah bahkan paud. Penerapan pembelajaran daring ini merupakan suatu wujud pemanfaatan media di generasi ini yang diunggulkan karena sangat mengefisienkan keadaan. Seperti yang telah disampaikan oleh Keengwe dan Georgina pada penelitiannya bahwa teknologi yang terus maju akan mempengaruhi proses belajar (Khusniyah \& Hakim, 2019).

Disini pembahasan akan terfokus pada pembelajaran daring di bangku perkuliahan. Pembelajaran daring dilakukan menggunakan bantuan teknologi internet. Teknologi internet adalah suatu media yang mampu menjangkau ke seluruh dunia (LaQuery). Pernyataan ini menjadi bukti adanya internet adalah suatu jaringan mancanegara yang dihubungkan oleh komputer di muka bumi ini. Informasi yang diwakilkan oleh komputer akan terhubung dengan internet sebagai media utamanya, telah mampu memberikan kontribusi yang demikian besar bagi proses pendidikan. E-education (Electronic Education) ialah istilah penggunaan IT (Information Technology) di bidang Pendidikan. Internet menjadi sumber informasi yang pada mulanya sulit untuk diakses, kini tidak menjadi problem (Hidayat, 2015).

Mengingat pembelajaran daring bukan saja baru diterapkan saat ini tetapi sudah jauh lebih dulu, hanya saja yang menerapkan pembelajaran ini mata kuliah tertentu. Perbandingan dengan dengan saat ini di seluruh mata kuliah menerapkannya. Dan penggunaan sistem ini tidak 
mudah seperti yang dibayangkan, tentunya membutuhkan media software seperti aplikasi. Pembelajaran daring yang diterapkan pada mahasiswa menggunakan aolikasi yang beragam (Wa, Ig, Youtube, GC, Edmodoo, dan lain-lain) sangat mengemangkan kesempatan interaksi. Sebagai teknologi yang sangat dibutuhkan, internet adalah salah satu media yang cara pengaplikasiannya mudah dan sangat efisiensi sekali begitupun sangat efektif belajar online. dengan internet dapat dilakukan pembelajaran baik serentak atau peroranagn sehingga lebih efisien dari cara pengajaran (Rossi, 2013). Penggunaan aplikasi ini tidak instan orang langsung paham banyak mahasiswa yang masih kesulitan dalam pengaplikasiannya bahkan buka cuma mahasiswa dosen yang baru menerapkan sistem ini terkadang masih merasa bingung dan membutuhkan bantuan dari penanggung jawab kelas yang tentunya sama-sama baru memahami. karena kebingungan yang sudah tidak dapat diselesaikan banyak dosen yang mengambil keputusan untuk memberikan tugas setiap kali pertemuannya.

\section{Dampak dari Pembelajaran Daring}

Dengan seringnya dosen memberikan tugas, hal inilah yang menjadi penyebab banyak ditemukan keluhan-keluhan dari mahasiswa, bukan berarti ada kesalahan dari sistem yang diterapkan tetapi karena amunisi yang diberikan terlalu sering sehingga memberi kesan yang memberatkan pada mahasiswa. Tidak sedikit mahasiswa yang menyatakan ketidaksanggupannya dalam mengerjakan tugas. Ketidaksanggupan ini tidak mengakar pada kesulitan tugas yang diberikan tetapi durasi pengerjaannya yang memakan waktu yang cukup lama. Sehingga dalam mengerjakan tugas bisa sampai larut malam yang sebenarnya tidak baik dalam pandangan kesehatan. Karena kualitas tidur sangatlah mempengaruhi kesehatan individu seseorang.

Kualitas tidur yang buruk akan menjadikan kualitas kesehatan baik fisik atau psikologi menurun. Dalam pandangan Islam rahasia tidur dalam Al-Qur'an sangat. Sebagai makhluk yang memiliki kebutuhan, tidur menjadi sebuah kebutuhan dalam diri seseorang dalam mengistirahatkan selurh organ dari sibuknya aktivitas kesehariannya. Dan mempersiapkan diri untuk aktivitas berikutnya. Namun dari sisi Islam tidur adalah suatu proses yang tidak jelas yang terdapat dalam diri manusia untuk berhubungan dengan wilayah tertentu, baik denga Tuhannya atau berhubungan dengan dimensi mimpinya (Setiawan, 2016). Kilas balik pada kualitas tidur secara fisiologis, kualitas tidur yang tidak benar akan sangat mudah membuat menurunnya tingkat kesehatan individu dan memicu kelelahan yang tinggi. Jika dari segi psikologis, kurangnya kualitas tidur akan berpengaruh pada emosional seseorang, lebih sensitif, Secara psikologis, implusif yang berlebihan sampai kecerobohan (Sulistiyani, 2012). Akibat dari kurang tidur yang berkepanjangan sangatlah berbahaya, Sebenarnya pola tidur pada seseorang yang sudah dewasa (usia 18-40 tahun) tidak jauh berbeda dengan jumlah tidur pada saat usia remaja, yaitu 7-8 jam/hari pola normalnya. Sama halnya dengan usia dewasa menengah sekitar 40-60 tahun. Sedangkan pada usia dewasa tua pola tidur seseorang akan berubah, mungkin karena insomnia dan susah tidur. Sehingga waktu tidur pada dewasa tua hanya 6 jam/hari, sebab itu waktu terjaganya lebih besar. (Yuliwar, 2018).

Selain itu dampak dari pembelajaran daring ini mampu membuat mahasiswa mudah terserang stress kerja. Stress kerja merupakan interaksi dari beberapa faktor, yaitu stres di pekerjaan itu sendiri sebagai faktor eksternal, dan faktor internal seperti karakter dan persepsi dari mahasiswa itu sendiri. Dengan kata lain, stres kerja tidak semata-mata disebabkan masalah 
internal, sebab reaksi terhadap stimulus akan sangat tergantung pada reaksi subyektif individu masing-masing. Beberapa sumber stres yang dianggap sebagai sumber stres kerja meliputi kondisi pekerjaan, konflik peran, struktur organisasi, dan pengembangan mahasiswa. Adapun stres model stimulus merupakan model stres yang menjelaskan bahwa stres itu adalah variabel bebas (independen) atau penyebab manusia mengalami stres (Lyon, 2009). Ataupun dengan kata lain, stress adalah keadaan lingkuangan yang dirasakan seseorang sanagat mengecam (Bartlet, 1998) dan individu itu hanya menerima stimulus stres tanpa proses pencernaan yang baik (Staal, 2004). Sebab stres tersebut berperan dalam menentukan berapa yang kemungkinan manusia terima. Sehingga tekanan yang berasal dari keadaan sekitar bisa menjadi penyebab dan penentu pada kesehatan apabila terjadi dalam kurun waktu yang sering dan dengan jumlah yang berbahaya (Tua \& Gaol, 2016).

Menurut Terry Beehr dan John Newman, gejala stres kerja terbagi menjadi 3 aspek yaitu gejala psikologis, gejala psikis, dan perilaku. Gejala psikologis meliputri kecemasan, ketegangan, bingung, marah, sensitif memendam rasa, komunikasi tidak efektif, mengurung diri, kebosanan, depresi, merasa terasing dan mengasingkan diri, ketdakpuasan kerja, lelah mental menurunnya fungsi itelektual, kehilangan daya konsentrasi, kehilangan spontanitas dan kreativitas, kehilangan semangat hidup, menurunnya kepercayaan dan rasa percaya diri. Gejala fisik, meliputi meningkatnya detak jantung dan tekanan darah, meningkatnya sekresi adrenalin dan noadrenalin, gangguan gastrointestinal. Gejala psikis, misalnya gangguan lambung, mudah terluka, mudah lelah fisik, kematian, lebih sering berkeringat, gangguan pada kulit, gangguan kardiovaskuler, gangguan pernapasan, kepala pusing, migrain kanker, ketegangan otot, problem tidur (Eunike R. Rustiana; Widya Hary Cahyati, 2012).

Bagian Stres yang terjadi tidak lain otak mengalami kekurangan hormon suasana hati atau hormon dopamin, karena hormon dopamin dalam neurosains merupakan salah satu neurotransmitter. Neurotransmitter adalah senyawa pada tubuh manusia yang beran menyapaikan stimulus antara satu sel saraf (neuron) ke sel saraf target. Sel ini dapat berada pada otot, berbagai kelenjar, dan bagian lain dalam tubuh. Dalam neurosains dopamin atau dikenal dengan nama IUPAC 4-(2-aminoethyl)benzene-1,2-diol (DA) adalah salah satu dari katekolamin alami yang sangat penting sebagai neurotransmitter dalam sistem hormon, sistem sarafkardiovaskuler dan saraf pusat. Banyaknya dopamin yang harus di salurkan pada organ tubuh mempunyai pengaruh yang sangat besar pada emosional manusia dan secara langsung konteks dengan berbagai penyakit karena konsentrasi rendah yang diluar batas normal dari dopamin. Sehingga berimbas akan terjangkitnya beberapa gangguan neurologis seperti; skizofrenia, penyakit huntington, penyakit parkinson, dan bahkan infeksi HIV (Irdhawati et al., 2015).

Ketika produksi hormon dopamin mengalami penurunan secara tidak langsung mahasiswa mengalami stres dan tekanan batin yang sangat tinggi. Dari tugas yang selalu terbayang-bayang setiap kali melakukan sesuatu, dan tidak optimalisasi dalam berfikir secara jernih. Faktor eksternal juga berpengaruh sebab kebebasan aktivitas diluar sangat terbatas sebelum pandemi virus corona dapat diatasi. Selain itu perkuliahan daring juga membutuhkan paket internet untuk melancarkan prosesnya. Hal ini juga menjadi faktor yang mempengaruhi terjadinya keluhan oleh para mahasiswa. Penggunaan internet yang sering dan aplikasi yang besar cukup banyak menghabiskan kuota data mahasiswa. Saat ini, hanya melalui smartphone 
saja kita bisa menjelajahi dunia dengan internet. Namun tentu saja, memastikan bahwa telepon genggam mempunyai paket data internet dan memiliki jumlah kuota yang sudah di tentukan oleh operator jaringan. Paket Internet adalah bentuk media pelayanan yang disediakan oleh operator telekomunikasi atau bentuk data yang harus dibayar dalam satuan rupiah sebagai biaya pemakaian internet (data). Bagi pengguna yang tidak menggunakan paket internet/kuota data secara otomatis akan memakan pulsa seluler atau jika tidak memiliki pulsa koneksi tidak akan tidak terhubung (Fitriyani; Ellya Helmud, 2016).

\section{Data Wawancara via What's App}

Wawancara (interview) adalah proses pengumpulan informasi dalam suatu penelitian sosial, dan peneliti bertanya langsung kepada narasumber baik secara langsung atau menggunakan media (Rosaliza, 2015). Berikut adalah hasil pernyataan wawancara secara komunikasi personal pada mahasiswa Universitas Ahmad Dahlan melalui via whatsapp. Ananda Riski Hakim mahasiswa Fakultas Keguruan dan Ilmu Pendidikan menyatakan bahwa dengan perkuliahan daring pada penerapannya sedikit mengagetkan dan merasa stress karena terbebani oleh tugas yang tidak ada habisnya serta waktu perkuliahan online masih berpatok pada jadwal pada sistem perkuliahan secara langsung, dan dosen ketika berdiskusi online tidak segera memulai diskusi jika peserta didik belum mengakses seluruhnya, seharusnya harus efisiensi waktu dan on time (Komunikasi Personal, 26 April 2020). Menurut Teguh Bayu Aji mahasiswa Fakuatas Tekhnologi Industri, yang tidak menyenangkan dalam perkuliahan dari segi materi yang disampaikan sulit untuk dipahami, dan banyaknya tugas dengan deadline yang terlalu cepat (Komunikasi Personal, 26 April 2020). Narasumber lain menelaskan terlebih berdasarkan yang saya rasakan dengan tugas yang terlampau banyak membuat saya sangat terbebani sekali (Syaiful Risani, 26 April 2020). Miqdad Abdul Majid mengatakan bahwa perkuliahan daring sangat merepotkan, saya harus mencari sinyal dan terbebani di segi kuota yang boros (Komunikasi Personal, 26 April 2020). Berdasar beberapa pernyataan mahasiswa Universitas Ahmad Dahlan diatas adalah beberapa aspirasi atau pendapat yang diseleksi mewakili beberapa pernyataan mahasiswa yang sama. Sehingga dengan pernyataan yang nyata dari mahasiswa ini cukup memberikan bukti yang kuat dalam penelitian terkait. Wawancara ini berbentuk tidak berstandar sebab setiap pertanyaan yang di berikan kepada narasumber tidak teragendakan (Rachmawati, 2007).

\section{Pandangan Neurosains Terhadap Stres}

Mengingat neurosains ilmu yang mempelajari sel saraf pada otak (Suyadi, 2018). Sehingga problem ini sangat berkaitan konsep akal dalam neurosains, karena penyebab utama stres berasal dari otak. Setiap asupan pengetahuan yang masuk ke otak dan direspon oleh otak menjadi sel memori yang selalu teringat bila terulang atau behavioristik. Teori belajar behavioristik adalah teori yang membahas perubahan sikap sebab dari pengalaman. Teori ini sangat membantu pada bidang psikologi baik segi pendidikan atau praktik (RK Rusli; MA Kholik, 2013). Aliran ini menekankan pada terbentuknya perilaku yang tampak sebagai hasil belajar. Filasafat dan ilmu pengetahuan yang ada sejak kurang lebih 600 SM di Yunani. Salah seorang pemikir Yunani memanfaatkan akal untuk mengemangkan pengetahuan adalah suatu keniscayaan yang tidak bisa dipisahkan. Sebab akal dan ilmu pengetahuan setara dengan filsafat 
yang sangat dibutuhkan (Astuti Budi Handayani; Suyadi, 2019).

Sedangkan ketika otak memiliki sensitifitas atau stres, ini akan menimbulkan pemikiran akal yang berbeda dari biasanya. Bisa saja orang tersebut akan memiliki emosional dan kesesitifan yang lebih tinggi. Stres merupakan respon dibawah sadar yang disebabkan oleh situasi yag engancam. Stres mengakktifkan aksis HPA dan sistem simpatoadrenomedular sehingga meningkatkan produksi corticotropin-releasing hormone ( $\mathrm{CRH})$ dan argininevasopressin (AVP). Hal ini menyebabkan peningkatan episode sekresi adrenocoticotropic hormone $(\mathrm{ACTH})$ dan glukokortikoid, sekaligus menurunkan ekspresi reseptor glukokortikod. Glukokortikod mampu melewati sawar darah otak, dan berinteraksi dengan glucocortikoid responsive elements (GREs) dari gen pada sistem (Juananda et al., 2015). Glukokortikoid terbukti mengganggu stabilitas sel pusat, dan menurunkan translasi protein yang terlibat dalam potensial saraf pusat. Stres yang terjadi di lingkungan pendidikan biasanya disebut dengan stres akademik. Stres akademik adalah stres yang mulanya terjadi disebabkan oleh academic stresor. Academic stresor adalah stres yang dialami oleh seorang peserta didik atau mahasiswa yang bersumber pada aktivitas belajar dan mengajar atau yang terkait seperti, nilai rapot/IPK, tugas yang banyak, kecemasan saat ujian, ataupun soal yang sulit. (Barseli \& Ifdil, 2017).

Bila ego berfungsi dengan baik maka semua akan dalam keseimbangan yang baik pula. Apabila stresor yang terjadi dapat diatasi secara menyeluruh tidak akan mengakibatkan stres. Bila terjadi ketidaksanggupan dalam sistem pengendalian egonya, baru akan menimbulkan stres. Dan tidak selamanya seseorang mampu mengatasi stresor ini. Bila gangfguan keseimbangan ini terjadi cukup lama dan sulit diatasi kemungkinan akan menimbulkan penyakit berat.

Menghadapi stresor berarti memberi individu yang terdampak dengan pelajaran sehingga lebih cekatan di kemudian hari nanti dengan kemungkinan memperkembangkan kemampuan dan strategi pengatasan stresor yang serupa. Justru dapat pula memberikan ide-ide menakutkan yang terikat dengan berbagai emosi tertentu dan berkaitan dengan upaya mengatasi stresor yang sama (Musradinur, 2016).

\section{Pandangan Islam Mengenai Stres dan Upaya Mencegah}

Pandangan Islam terhadap stres, situasi yang sangat megecam ini menjadi suatu keadaan yang akan sulit diatasi oleh seseorang. Seringkali membutuhkan waktu yang cukup lama utuk mengatasinya dan tidak sedikit pula yang gagal dalam berupaya mengatasinya, sehingga stres yang timbul akan mempengaruhi aktrivitas keseharian. Islam memandang stres dalam kehidupan ini adalah tidak lain hanya sebuah cobaan yang Allah berikan kepada umatnya. Allah SWT berfirman di dalam Al-Qur'an surat Al-Baqarah (2) ayat 155, yang artinya; "dan sungguh akan kami berikan cobaan kepadamu, dengan sedikit ketakutan, kelaparan, kekurangan harta, jiwa, dan buah-buahan. Dan berikanlah kabar gembira kepada orang-orang yang sabar" (Yuwono, 2010). Manusia adalah makhluk ciptaan Allah yang tidak sempurna, namun kesempurnaan itu hadir etika manusia memiliki akal dan pikiran, pembeda dari makhuk ciptaan Allah lainnya. Akal dan pikiran merupakan modal awal manusia untuk mempertahankan eksistensi sebagai makhluk Allah. Dan kesempurnaan manusia hanya dalam tataran atau sudut makhluk saja, karena Allah menciptakan manusia dengan kekurangan dan kelebihan. Manusia adalah tempa salah dan berdosa.

Gangguan stres ini merupakan gejala penyakit yang cukup mendominasi di abad modern 
ini. Berbagai macam upaya yang ditujukan untuk mengatasi dan mengurangi munculnya permasalaan terkait, diantaranya dengan menggunakan pendekatan agama. Ajaran agaa lebih menyentuh dalam segi qolbu atau sifat dasar manusia (fitrah) seperti yang ada dalam QS. AlBaqarah (2) ayat 286 pada dasarnya "bahwa Allah tidak akan membebani seseorang melainkan sesuai dengan kesanggupannya". Ayat ini sangat dianjurkan untuk dihayatri dan dipahami apa intisarinya dalam kehidupan, pasti mampu mengelola kecenderungan dan menetralisir stres yang dialami (Zaharuddin, 2014).

Adapun cara dalam menurunkan stres dengan pendekatan agama bermacam salah satunya menggunakan Al-Qur'an yang disebut jga As-Syifa yang berarti penyembuh, dan mustahil hidangan ternikmat dimuka bumi ini dan tidk akan membawa peubahan dalam upaya penanganan masalah yang ada terkhususnya stres. QS. Yunus ayat 57 telah mencoba menjelaskan, yang artinya "hai manusia, sesungguhnya telah datang kepadamu pelajaran dari Tuhanmu dan penyembuh bagi penyakit-penyakit (yang berada) dalam dada dan petunjuk serta rahmat bagi orang-orang yang beriman". QS. Al-Isra ayat 82 juga menjelaskan, bahwasannya “ dan kami turunkan dari Al-Qur'an suatu yang menjadi penyembuh dan rahmat bagi orang-orang yang beriman dan Al-Qur'an itu tidaklah menambah kepada orang-orang yang zalim selain kerugian”. Dan juga pada QS. AR-Rad ayat 28 yang berbunyi “(yaitu) orang-orang yang beriman dan hati mereka menjadi tentram dengan mengingat Allah, ingatlah hanya dengan mengingat Allah hati menjadi tentram”. Dari pernyataan ayat Al-Qur'an diatas menunjukan bahwa Al-Qur'an adalah obat dari segala macam penyakit, termasuk penyakit hati yangmampu menimbulkan stres. Dengan didukung dengan spiritualitas berupa doa, ketawakalan, keiklasan, kemukhsinan, serta dzikir. Insyaallah denngan energi kebaikan ini mampu mempengaruhi dan memperbaiki kondisi psikologis seseorang dan pada akhirnya mampu menurunkan stres (Stanislaus, 2018).

\section{KESIMPULAN}

Pembelajaran daring yang diterapakan secara massal dapat berpengaruh besar terhadap konsep akal. Timbul stress sudah semestinya terjadi ketika pola pikir tidak mampu mencapai pemahaman di luar persepsi mahasiswa masing-masing. Ketenangan sangat penting dalam kehidupan tentunya dengan ketenangan yang berdasarkan pada pendekatan agama. Dan penelitian ini berupaya mengekspresikan keluhan yang semestinya memang harus didengar.

Semoga kedepannya peningkatan, pengembangan, dan optimalisasi layanan bimbingan dan konseling untuk pengelolaan stres akademik dapat terselenggara, perlunya layanan bimbingan dan konseling untuk menurunkan level stres yang dialami mahasiswa. sehingga mahasiswa mendapatkan bantuan dalam pengoptimalan mengatasi stress yang teramat.

\section{DAFTAR PUSTAKA}

Astuti Budi Handayani; Suyadi. (2019). Relevansi konsep akal bertingkat Ibnu Sina dalam pendidikan Islam di Era Milenial. Jurnal Pendidikan Islam Ta'dibuna, 8(2), 222-240. https://doi.org/10.32832/tadibuna.v8i2.2034

Awada, G. (2016). Effect Of Whatsapp On Critique Writing Proficiency and Perceptions Toward Learning Effect Of Whatsapp On Critique Writing Proficiency and Perceptions Toward Learning. Cogent Education, 6(1), 1-25. https://doi.org/10.1080/2331186X.2016.1264173 
Barseli, M., \& Ifdil, I. (2017). Konsep Stres Akademik Siswa. Jurnal Konseling Dan Pendidikan, 2005, 143-148.

Bartlet, D. (1998). Stress Perspectives and Processes.

Eunike R. Rustiana; Widya Hary Cahyati. (2012). Stress Kerja Dengan Pemilihan Strategi Coping. Jurnal Kesehatan Masyarakat, 7(2), 149-155.

Fauzia, F. R. V. Y. P. S. A. A. J. H. (2020). Bunga Rampai Covid-19: Buku Kesehatan Mandiri Untuk Sahabat.

Fitriyani; Ellya Helmud. (2016). Pemilihan Paket Internet Android Pada Operator Telepon Gsm Menggunakan Metode Analytical Hierarchy Process (AHP). Jurnal Sistem Informasi (JSI), $8(1), 918-927$.

Hidayat, R. (2015). Analisis Tingkat Penggunaan Internet dikalangan Mahasiswa dan Hubungannya dalam Peningkatan Nilai Akademik ( Studi Kasus pada Mahasiswa di Kota Medan ). Jurnal Mediasi, 2(2), 55-63.

Irdhawati, I., Manurung, M., \& Septiawan, K. (2015). Deteksi Dopamin Secara Voltametri Menggunakan Elektroda Pasta Karbon Termodifikasi Eter Mahkota (Dibenzo-18-Crown-6). Jurnal Kimia Mulawarman, 12(2), 68-74.

Juananda, D., Cahyani, D., Sari, R., Prakosa, D., Arfian, N., \& Romi, M. (2015). Pengaruh Stres Kronik terhadap Otak: Kajian Biomolekuler Hormon Glukokortikoid dan Regulasi BrainDerived Neurotrophic Factor ( BDNF ) Pascastres di Cerebellum. JIK, 9(2), 65-70.

Kampf, G., Todt, D., Pfaender, S., \& Steinmann, E. (2020). Persistence Of Coronaviruses On Inanimate Surfaces And Their Inactivation With Biocidal Agents. Journal of Hospital Infection, 104(3), 246-251. https://doi.org/10.1016/j.jhin.2020.01.022

Khusniyah, N. L., \& Hakim, L. (2019). Efektifitas Pembelajaran Berbasis Daring: Sebuah Bukti Dalam Pembelajaran Bahasa Inggris. Jurnal Tatsqif, 17(1), 19-33.

Kuntarto, E. (2017). Keefektifan Model Pembelajaran Daring Dalam Perkuliahan Bahasa Indonesia Di Perguruan Tinggi. Journal Indonesian Language Education And Literature, 3(1), 99-110. http://www.syekhnurjati.ac.id/jurnal/index.php/jeill/\%0APEMBELAJARAN Lyon, B. L. (2009). Stress, Coping, and Health (Issue 1).

Mulyadi, M. (2011). Penelitian Kuantitatif Dan Kualitatif Serta Pemikiran Dasar Menggabungkannya. Jurnal Studi Komunikasi Dan Mediai, 15(1), 127-138.

Musradinur. (2016). Stres dan Cara Mengatasinya Dalam Perspektif Psikologi. Jurnal Edukasi, 2(2), 183-200.

Mustofa, M. I., Chodzirin, M., Sayekti, L., \& Fauzan, R. (2019). Formulasi Model Perkuliahan Daring Sebagai Upaya Menekan Disparitas Kualitas Perguruan Tinggi. Walisongo Journal of Information Technology, 1(2), 151-160. https://doi.org/10.21580/wjit.2019.1.2.4067

Rachmawati, I. N. (2007). Pengumpulan Data Dalam Penelitian Kualitas. Jurnal Keperawatan Indonesia, 11(1), 35-40.

RK Rusli; MA Kholik. (2013). Teori Belajar Dalam Psikologi Pendidikan Theory Of Learning According To Educational Psychology. Jurnal Sosial Humaniora, 4(2), 62-67.

Rosaliza, M. (2015). Wawancara, Sebuah Interaksi Komunikasi Dalam Penelitian Kualitatif. Jurbal Ilmu Budaya, 11(2), 71-79.

Rossi, P. G. (2013). The Effectiveness of Instruction-Oriented Hypertext Systems Compared to Direct Instruction in e-learning Environments The Effectiveness of Instruction-Oriented 
Hypertext Systems Compared to Direct Instruction in e-learning Environments. Contemporary Educational Technology, 281-308. https://doi.org/10.30935/cedtech/6109

Saifurrahman; Suyadi. (2019). Desain Pembelajaran Keagamaan Islam Berbasis Neurosains. AlMurabbi, 6(1), 55-73.

Setiawan, W. (2016). Al Quran Tentang Lupa Tidur, Mimpi, Dan Kematian. Al Murabbi, 2(2), 251-270.

Staal, M. A. (2004). Stress, Cognition, and Human Performance: A Literature Review and Conceptual Framework (Issue 1).

Stanislaus, D. N. M. I. M. S. (2018). Efektivitas Membaca Al-Qur'an Untuk Menurunkan Stres Akademik Pada Siswa Kelas Xi SMA Negeri 1 Kebumen. Jurnal Psikologi Ilmiah, 10(1), 59-71.

Sulistiyani, C. (2012). Beberapa Faktor Yang Berhubungan Dengan Kualitas Tidur Pada Mahasiswa Fakultas Kesehatan Masyarakat Universitas Diponegoro Semarang. Jurnal Kesehatan Masyarakat, 1(2), 280-292.

Suyadi. (2018). Diferensiasi Otak Laki-laki dan Perempuan Guru Taman Kanak-kanak Aisyiyah Nyai Ahmad Dahlan Yogyakarta: Studi Pendidikan Islam Anak Usia Dini Perspektif Gender dan Neurosains. Sawwa: Jurnal Studi Gender, 13(2), 179-202. https://doi.org/10.21580/sa.v13i2.2927

Tua, N., \& Gaol, L. (2016). Teori Stres: Stimulus , Respons , dan Transaksional. Buletin Psikologi, 24(1), 1-11. https://doi.org/10.22146/bpsi.11224

Wilder-Smith, A., \& Freedman, D. O. (2020). Isolation, Quarantine, Social Distancing And Community Containment: Pivotal Role For Old-Style Public Health Measures In The Novel Coronavirus (2019-Ncov) Outbreak. Journal of Travel Medicine, 27(2), 1-4. https://doi.org/10.1093/jtm/taaa020

Yuliwar, W. N. A. R. (2018). Hubungan Kualitas Tidur Dengan Tekanan Darah Pasien Hipertensi. Jurnal Berkala Epidemiologi, 6(1), 18-26. https://doi.org/10.20473/jbe.v6i12018.18-26

Yuwono, S. (2010). Mengelola Stres Dalam Perspektif Islam dan Psikologi. Psycho Idea, 8(2), $14-26$.

Zaharuddin. (2014). Stres Menghadapi Musibah Perspektif Islam ditinjau dari Adversity Quotient di Panti Asuhan di Kecamatan Plaju Palembang. Intizar, 20(2), 285-301. 